\title{
POTRET SOSIOLOGIS HUKUM ISLAM DI INDONESIA
}

\author{
Agus Sunaryo*
}

\section{Abstract}

The ability of Islamic law in solving society problems performs a unique creature as the model of Islamic law in Indonesia. Some processes which have proved its existence among the pluralism in Indonesia can be analyzed socially and bistorically.

Kata kunci: dialektika bukum Islam, bukum adat, konfigurasi politik

\section{A. Pendahuluan}

Kajian hukum Islam dalam konteks masyarakat Indonesia nampaknya selalu menarik dan senantiasa menyisakan lahan kosong untuk terus digarap. Hal ini paling tidak di dasarkan pada beberapa hal, antara lain: pertama, kehadiran agama Islam di Indonesia lengkap dengan sistem hukumnya, tidaklah berada di kawasan hampa. Jauh sebelum kedatangan Islam, masyarakat Indonesia sudah lebih dahulu memiliki kepercayaan baik berupa kepercayaan animisme maupun dinamisme. Lebih dari itu, agama Hindu dan Budha juga sudah memiliki penganut yang cukup banyak dari seluruh populasi masyarakat Indonesia kala itu. Dan terkait dengan aturan hukum, masyarakat juga sudah memiliki.suatu

- Penulis adalah alumni Prodi Hukum Islam Program Pascasarjana UIN Sunan Kalijaga dengan Konsentrasi Hukum Keluarga, calon dosen STAIN Purwokerto. 
sistem hukum yang hidup (living law) dan dipraktikkan dalam kehidupan mereka.

Kedua, terdapat dilema di mana bangsa Indonesia yang secara kuantitatif memiliki penganut Islam mayoritas (bahkan di dunia), dalam persoalan hukum tidak menerapkan sistem hukum Islam sebagaimana di terapkan di negara-negara Islam. Bahkan dalam persoalan dasar serta ideologi negara, bangsa Indonesia tidak menggunakan al-Qur'an, melainkan konsep yang digali dari nilainilai luhur bangsa Indonesia yang kemudian disebut dengan Pencasila. Dalam konteks ini, Pancasila diyakini sebagai satu-satunya asas yang bisa menjadi kalimatun sawā' (titik temu) serta margin of apreciation terhadap berbagai entitas yang ada di Indonesia. ${ }^{1}$

Ketiga, terjadinya dialektika antara hukum Islam dengan segala aspek di luarnya, ternyata telah membawa perubahan signifikan terhadap hukum Islam, khususnya di Indonesia. Hal ini menyangkut model, bentuk serta materi yang dikandung oleh hukum tersebut. Anti klimaks dari dialektika ini adalah lahirnya apa yang disebut dengan era unifikasi bukum sebagai konsekuensi logis dari gejala positivisme di bidang hukum.

Makalah ini akan mencoba mengurai bagaimana hukum Islam di Indonesia telah berevolusi sehingga menemukan bentuknya seperti sekarang. Sebuah bentuk yang diharapkan mampu menjadi mediator bagi terciptanya keadilan di tengah-tengah masyarakat Indonesia yang multikultural dan multireligious.

\section{B. Hukum Islam versus Hukum Adat; sebuah Hubungan Dialektis}

Pada tataran konsep, hukum Islam atau yang sering disebut fiqh dimaknai oleh para ahli dengan "pengetabuan tentang bukum-bukum

${ }^{1}$ Marzuki Wahid dan Rumadi, Fikib Mazhab Negara (Jogjakarta: LKiS, 2001), hal. 1. Tentang Pancasila sebagai margin of apreciation bisa dilihat pada Muladi, "Pancasila sebagai Margin of Apreciation dalam hukum yang hidup di Indonesia", dalam Ahmad Gunawan BS dan Mu'amar Ramadhan, Menggagas Hukum Progresif Indonesia (Jogjakarta: Pustaka Pelajar, 2006), hal. 197-220 
syari'at yang bersifat praktis yang digali dari petunjuknya yang bersifat rinci". ${ }^{2}$ Berdasarkan pengertian ini, bisa dipahami bahwa hukum Islam secara konseptual bersifat theosentris. Artinya, meskipun secara praktis ia tidak hanya mengatur hubungan antara manusia dengan Tuhannya, melainkan juga mengatur relasi antar manusia (mu'ämalät). Namun semua aturan yang dirumuskan selalu dibingkai dengan sebuah penisbatan hukum yaitu shar'iyyab ${ }^{3}$ (hukum yang berdasarkan wahyu Tuhan). ${ }^{4}$

Menarik untuk diperhatikan, pernyataan Qodri Azizy yang menyebutkan bahwa fikih atau Islamic Jurisprudence tidak selalu identik dengan law/rules atau peraturan perundang-undangan. Hukum Islam yang mencakup al-aḅkam al-khamsab (halal, haram, sunnah, makruh dan mubah) menegaskan bahwa fikih tidak bisa dipisahkan dengan apa yang disebut sebagai "etika agama" (religious ethics). Ciri utama dari keterpautan ini adalah adanya konsekuensi yang harus diterima dari "nilai ibadah" seseorang, baik itu berupa pahala (thawāb) ataupun siksaan ('iqāb). Lebih jauh lagi, konsekuensi tersebut akan terus berlanjut hingga di kehidupan mendatang (akhirat). Melihat fenomena ini, Qodri Azizy membuat kesimpulan bahwa fikih atau hukum Islam secara umum dapat diartikan dengan ilmu tentang perilaku manusia yang landasan utamanya adalah nas (wahyu). ${ }^{5}$

Dilihat dari aspek tujuannya, hukum Islam tidak memiliki perbedaan berarti dengan sistem hukum yang lain. Hukum Islam hadir untuk mengintegrasikan dan mengakomodir beragam kepentingan yang pada kondisi tertentu dapat saling 'bertubrukan'

${ }^{2}$ Sahal Mahfudz, Nuansa Figh Sosial (Jogjakarta: LKiS, 2003), hal. xxix. Lihat juga Abdul Wahāb Khallāf, Ilmu Ușul Fiqh (Kuwait: Dār al-Ilm, 1978), hal. 11

${ }^{3}$ Dalam konteks ini, syari'at tidak lain adalah penjelmaan kongkrit dari kehendak Allah (as-Syäri) di tengah-tengah kehidupan masyarakat. Lihat Ilyas Supena dan M. Fauzi, Dekonstruksi dan Rekonstruksi Hukum Islam (Jogjakarta: Gama Media, 2002), hal. 3

${ }^{4} \mathrm{Hal}$ ini tentunya berbeda dengan sistem hukum Eropa (civil law) atau anglo saxon (common law), di mana keduanya lebih bersifat antroposentris dengan menjadikan manusia sebagai pusat kegiatan hukum.

${ }^{5}$ Qodri Azizy, Hukum Nasional; Eklektisismen Hukum Islam dengan Hukum Umum (Jakarta: Teraju, 2004), hal. 30-31 
dan tidak menutup kemungkinan dapat memunculkan chaos di tengahtengah masyarakat. ${ }^{6}$ Menurut para juris Islam (fuqāhā'), tujuan akhir dari penerapan hukum Islam adalah terwujudnya kemaslahatan bagi masyarakat. Dan mengingat bahwa kemaslahatan yang dimaksud sangat terikat dengan konteks zaman (tempus) dan tempat (locus), maka hukum Islam pun selalu bergerak menyesuaikan diri dengan dinamika zaman tersebut.

Proses penyesuaian diri atau perubahan dalam hukum Islam (taghayyur al-abkām) bukanlah hal baru dalam sejarah legislasi Islam. Terbukti, banyak para ulama yang berbeda pendapat dalam menentukan hukum atas satu masalah dan ada pula beberapa ulama yang merevisi pendapatnya karena pertimbangan sosio-cultur masyarakat yang dihadapi. Hal ini pulalah yang membuat aturan hukum Islam selalu dapat bertahan dan applicable sepanjang zaman. ${ }^{7}$

Sebagai sebuah produk pemikiran yang diharapkan mampu menjawab segala persoalan kehidupan, hukum Islam tentu tidak harus bersikap arogan dengan mengesampingkan begitu saja norma masyarakat atau sistem hukum yang telah ada. Atas dasar itulah, seorang juris Islam terkenal Imam as-Syafi'i, membuat keputusan bijak untuk merevisi beberapa fatwa yang dirumuskannya ketika berada di Iraq (al-qawl al-qadim) dan menggantinya dengan fatwafatwa baru (al-qawl al-jadid) saat berada di Mesir. ${ }^{8}$

Demikianlah, bahwa dalam upaya mewujudkan kemaslahatan bagi kehidupan umat manusia, hukum Islam benar-benar mampu berdialektika secara positif dengan dunia di sekitarnya. Ia tidak hanya dituntut untuk beradaptasi dengan tradisi, norma atau aturan hukum yang ada, melainkan juga harus mampu memfungsikan diri sebagai a tool of social engineering yang ampuh dalam rangka menata kehidupan umat manusia menjadi lebih baik. Hanya dengan cara tersebut,

\footnotetext{
${ }^{6}$ Satjipto Raharjo, Ilmu Hukum (Bandung: Citra Aditya Bakti, 1996), hal. 56

${ }^{7}$ Uraian lebih lengkap mengenai elastisitas dan dinamisitas hukum Islam dapat dibaca pada NJ Coulson, Konflik dalam Jurisprudensi Islam, alihbahasa Fuad Zein Jogjakarta: Navila, 2001).

${ }^{8}$ Afi Hasaballāh, Ușül at-Tasyrì' al-Istāmì (Mesir: Dār al-Ma’ārif, t.t.), hal. 311.
} 
keyakinan umat Islam bahwa hukum Islam adalah sālị̣ likulli zamān wa makān (sesuai untuk segala masa dan tempat) dapat dibuktikan.

Dalam konteks bangsa Indonesia, perumusan serta penerapan hukum Islam nampaknya memiliki sejarah panjang dan latar sosiologis yang unik. Dan mungkin karena terlalu uniknya, beberapa sarjana dan peneliti modern sempat menganggap bahwa wajah Islam di Indonesia bukanlah wajah Islam yang sebenarnya. Oleh karena itu, jarang sekali mereka memasukkan Islam Indonesia ke dalam studistudi mengenai keislaman dan pembaharuan. Salah satu faktor munculnya asumsi ini adalah kuatnya unsur akulturasi antara ajaran Islam dengan tradisi dan budaya lokal serta posisi geografis kawasan nusantara yang berada pada pinggiran (periferi) dunia muslim. ${ }^{9}$

Bagi penulis, anggapan para peneliti di atas tidak semuanya harus disetujui. Corak khas keislaman di Indonesia, termasuk hukum Islamnya, justeru telah melahirkan gagasan-gagasan brilliant seperti Pribumisasi Islam, Reaktualisasi Islam, Islam Aktual atau Kontekstualisasi Islam. Beberapa gagasan ini membuktikan bahwa kajian keislaman di Indonesia begitu kaya dan justeru teramat sayang untuk diabaikan. Dengan demikian, mengidentikkan hukum Islam di Indonesia dengan hukum Islam di negara-negara Islam (Timur Tengah) lainnya, dalam beberapa kasus tentunya akan menjadi usaha yang kurang produktif (untuk tidak menyebut sia-sia).

Satu hal yang menarik dari fenomena bertemunya hukum Islam sebagai sistem hukum baru, dengan hukum adat (adatrecht) sebagai hukum yang telah membumi di Indonesia, adalah adanya titik temu antara keduanya terutama ketika membicarakan tujuan dan karakter masing-masing. Baik hukum Islam maupun hukum adat, keduanya memiliki tujuan menciptakan harmoni dan kedamaian dalam bingkai keadilan. Dan dari sisi karakter, keduanya sangat terbuka untuk menerima perubahan dan mudah beradaptasi dengan lingkungan sekitarnya. Salah satu bukti betapa antara hukum adat dan hukum

9 Azyumardi Azra, Jaringan Ulama Timur Tengab dan Kepulauan Nusantara Abad XVII dan XVIII (Jakarta: Kencana, 2004), hal. xix 
Islam mampu bertali-kelindan secara harmonis adalah semboyan adat masyarakat Minangkabau adat basandi syarak, syarak basandi kitabullah. Masyarakat Aceh juga memiliki semboyan adat bukum ngon adat bantom cre, lagee zat ngon sifeut (hukum Islam dan adat tak terpisahkan, seperti layaknya zat dan sifat dari suatu benda) dan masih banyak lagi semboyan adat serupa dari seluruh gugusan adat yang ada di wilayah nusantara. ${ }^{10}$

Meskipun secara substantif banyak kesamaan antara hukum adat dan hukum Islam, namun pada wilayah mana di antara keduanya yang harus diberlakukan di masyarakat, telah melahirkan setidaknya tiga teori, yaitu:

\section{Teori Receptio in Complexu}

Teori ini diperkenalkan pertama kali oleh seorang ahli hukum berkebangsaan Belanda bernama Salomon Keyzer yang kemudian dipertegas dan dikembangkan oleh L.W.C van Den Berg. Dalam teorinya, Berg menyatakan bahwa hukum yang diterapkan pada individu haruslah hukum yang sesuai dengan agamanya. ${ }^{11}$ Dalam hal ini hukum Islam haruslah diberlakukan sepenuhnya bagi orang Islam. Teori ini dibuktikan dengan adanya pengakuan VOC terhadap Hukum Keluarga Islam di Indonesia yang diakui dan dilaksanakan dalam bentuk peraturan Resolutie der Indische Regeering tanggal 25 Mei 1760. Peraturan ini merupakan kumpulan aturan hukum perkawinan dan kewarisan Islam yang pada waktu itu dikenal sebagai compendium freijer. Kemudian, hukum Islam ini oleh pemerintah Hindia Belanda diberi dasar hukum dalam regeeringsregiement $(\mathrm{RR})$ tahun 1855 di mana antara lain salah satu pasalnya (75) menyebutkan: "oleh hakim Indonesia itu hendaklah diberlakukan undang-undang agama". ${ }^{2}$

\footnotetext{
${ }^{10}$ Lihat Ratno Lukito, Tradisi Hukum Indonesia (Jogjakarta: Teras, 2008), hal. 65

${ }^{11}$ Sudirman Teba (ed.), Perkembangan Mutakbir Hukum Islam di Asia Tenggara (Bandung: Mizan, 1993), hal. 55-57

${ }^{12}$ Ismail Sunny, "Kedudukan Hukum Islam dalam Sistem Ketatanegaraan Indonesia", dalam Munawir Sadzali dan Juhaya S. Praja, Hukum Islam di Indonesia (Bandung: Remaja Rosdakarya, t.t), hal. 73
} 


\section{Teori Receptie}

Teori ini diperkenalkan oleh Snouck Hurgronje dan dikembangkan oleh Van Vollenhoven serta Ter Harr Bezn. Dalam teorinya, Snouck menolak apa yang dinyatakan oleh pencetus teori receptio in complexu. Menurutnya, hukum Islam tidak bisa diterapkan bagi siapapun apabila tidak dikehendaki atau diterima oleh hukum adat. Hukum Islam baru bisa diterapkan apabila hukum adat bisa menerimanya. Atas dasar teori ini, maka periode di mana hukum Islam dapat diterapkan sepenuhnya menjadi berakhir. Regeeringsreglement yang menjadi payung diberlakukannya hukum Islam di Indonesia diganti oleh pemerintah Belanda dengan Indische Staatsregeling (IS) yang mencabut pemberlakuan hukum Islam di lingkungan tata hukum Hindia Belanda. Dalam salah satu pasalnya (134), IS tahun 1929 menyatakan bahwa: "dalam hal terjadi perkara perdata antara sesama orang Islam akan diselesaikan oleh hakim Islam apabila hukum adat mereka menghendaki dan sejauh tidak ditentukan lain dengan suatu ordonansi". ${ }^{13}$

3. Teori Unifikasi

Teori ini oleh pemerintah Hindia Belanda semula ditujukan untuk menetralisir ketegangan antara hukum Islam dengan hukum adat dengan jalan melebur keduanya ke dalam satu sistem hukum yaitu continental system. Van Vollenhoven, sebagai menganut teori receptie menentang keras gagasan unifikasi hukum ini. Menurutnya, unifikasi hanyalah merupakan gagasan artificial dan tidak sesuai dengan kesadaran sosial masyarakat Indonesia.

Berdasarkan ketiga teori di atas, dapatlah dipahami bahwa hukum Islam di Indonesia memang sudah semestinya memiliki ciri dan corak yang khas dari pada yang ada di negara muslim lainnya. Tarik ulur yang sedemikian kuat antara hukum adat, kebijakan pemerintah kolonial dan hukum Islam itu sendiri pada akhirnya akan

${ }^{13}$ Ibid, hal. 73-74 
menyadarkan semua orang betapa eklektisitas yang terjadi tidak harus dipahami bahwa Islam di Indonesia sama sekali tidak mencerminkan wajah Islam yang sebenarnya. Yang terjadi justeru sebaliknya, yaitu hukum Islam di Indonesia benar-benar telah melalui fase uji materi, seleksi alam dan proses pendewasaan yang panjang. Dengan demikian tidak ada alasan lagi bagi siapapun untuk mengatakan hukum Islam di Indonesia itu usang dan ketinggalan zaman.

\section{Hukum Islam dan Konfigurasi Politik di Indonesia}

Di Indonesia, upaya reintroduksi hukum Islam dalam wacana kebangsaan sudah berlangsung cukup lama, bahkan sejak periode kerajaan-kerajaan besar Islam. Pada tahun $1628 \mathrm{M}$ misalnya, Nur ad-Din ar-Raniri sudah menulis kitab șirăt al-mustaqim . Kitab ini merupakan kitab pertama yang memuat segala permasalahan hukum Islam dan tersebar secara luas di kepualauan nusantara. Bahkan penjelasan (syarah) dari kitab ini yang ditulis oleh syaikh Arsyad al-Banjari dengan judul Sabil al-Mubtadin, dijadikan sebagai kitab hukum materiil dalam menyelesaikan perkara perdata antara orang-orang Islam di kesultanan Banjar. Tentunya kedua kitab tersebut masih menggunakan model dan sistematika layaknya kitab fikih klasik. ${ }^{14}$

Pada masa kolonial, sebagaimana telah dijelaskan di atas, praktek reintroduksi tersebut nampak pada lahirnya beberapa keputusan pemerintah Hindia Belanda seperti Compedium Freijer (1760), Cirebonasche Rechtboek (1757-1760) dan Compedium Indlansche Wetten bij de ven Bone en Goa. ${ }^{15}$ Kehadiran hukum pemerintah kolonial, meskipun dalam skala yang lebih umum sering membawa dampak negatif, namun dari perspektif yang lebih positif ia telah mening

${ }^{14}$ Muhammad Daud Ali, "Hukum Islam; Peradilan Agama dan Masalahnya", dalam Eddi Rudianan Arief et.al. (Peny), Hukum Islam di Indonesia (Bandung: Rosdakarya, 1991), hal. 71

${ }^{15}$ Cipto Sembodo, "Reintroduksi Hukum Islam dalam Wacana Kebangsaan", dalam Fakultas Syari'ah, Jurnal as-Syir'ah, No.8 tahun 2001 (Jogjakarta: Fakultas Syari'ah, 2001), hal. 77 
galkan pelajaran berharga tentang pentingnya kodifikasi hukum dalam menciptakan suatu kepastian hukum. Semangat kodifikasi yang mengadopsi prinsip-prinsip tradisi hukum romawi (roman law) inilah yang secara gamblang telah mempengaruhi perkembangan hukum Islam di Indonesia, terutama di era pasca kemerdekaan. ${ }^{16}$

Pasca kemerdekaan Republik Indonesia, upaya reintroduksi hukum Islam dalam perkembangannya telah melahirkan teori-teori baru tentang berlakukan hukum Islam di Indonesia. Apa yang dilakukan oleh Hazairin dengan merumuskan teori receptie exit ${ }^{7}$ dan Sajuti Thalib dengan teorinya receptio a contrario ${ }^{18}$ telah menunjukkan bahwa upaya reintroduksi hukum Islam dalam wacana kebangsaan Indonesia masih dilaksanakan dan semakin menemukan titik terang. Bahkan, sebagai tindak lanjut dari teori receptio a contrario, $\mathrm{H}$. Ichtijanto merumuskan sebuah teorri baru yang disebut dengan teori eksistensi. Menurutnya, hukum Islam itu harus "ada" (exist) dalam sistem hukum nasional. Konsep "ada" nya hukum Islam disini diartikan olehnya dengan:

1. Sebagai bagian integral dari hukum nasional

2. Dengan kemandirian dan kekuatan wibawanya ia diakui oleh hukum nasional serta diberi status sebagai hukum nasional

3. Berfungsi sebagai penyaring bahan-bahan hukum nasional

4. Sebagai bahan utama dan sumber utama hukum nasional. ${ }^{19}$

${ }^{16}$ Imam Mawardi, "Rationale Sosial Politik Pembuatan Kompilasi Hukum Islam di Indonesia, dalam Dody S. Truna dan Ismatu Ropi, Pranata Islam di Indonesia (Jakarta: Logos Wacana Ilmu, 2002), hal. 98

${ }^{17}$ Dalam teorinya, Hazairin menyatakan bahwa teori yang menolak pemberlakuan hukum Islam di Indonesia (teori receptie) harus keluar (exit) dari teori hukum nasional bangsa Indonesia, karena bertentangan dengan UUD 1945, al-Qur'an serta as-Sunnah. Lihat, Hazairin, Tujub Serangkai tentang Hukum (Jakarta: Tintamas, 1974), hal. 116

${ }^{18}$ Menurut Sajuti Thalib, hukum yang berlaku bagi masyarakat adalah hukum agamanya; hukum adat hanya berlaku jika tidak bertentangan dengan hukum agama. Lihat, Sajuti Thalib, Receptio a Contrario; Hubungan Hukum Adat dengan Hukum Islam (Jakarta: Bina Aksara, 1985), hal. 58-63

${ }^{19}$ H. Ichtijanto SA, Hukum Islam dan Hukum Nasional (Jakarta: Ind-Hill-Co, 1990), hal. $86-87$ 
Pemikiran hukum Islam dalam wacana kebangsaan di Indonesia nampaknya baru menemukan momentumnya setelah tahun 1970-an. Pada awal pemerintahan rezim Orde Baru, meskipun tidak ada sama sekali pointer dalam teks-teks hukum yang berkenaan dengan eksistensi hukum Islam, namun begitu hal ini bukan berarti hukum Islam tidak mendapatkan perhatian. Dalam kenyataan empiris di lapangan, hukum Islam ternyata mempunyai tempat dalam tata hukum nasional, paling tidak lebih baik jika dibandingkan dengan masa sebelumnya. Hanya saja, pemerintah Orde Baru nampaknya cenderung memasukkan hukum Islam sebagai bagian dari agama, bukan sebagai hukum otonom, yang secara mandiri dapat dikembangkan. Hal itu terlihat dengan jelas ketika pemerintah mencoba membuat pemisahan antara wilayah agama dan non agama. Pemisahan ini akhirnya melahirkan dikotomi antara hukum agama dengan hukum negara, seperti yang ditetapkan oleh UU No. 14 tahun 1970 tentang badan-badan peradilan di Indonesia. ${ }^{20}$

Jika ditarik mundur, kemajuan di bidang kodifikasi hukum Islam sebenarnya sudah mulai nampak ketika pemerintah mengeluarkan Peraturan Pemerintah No. 45 tahun 1957 tentang pembentukan Peradilan Agama di Luar Jawa dan Madura. Selain itu, keluarnya surat Edaran Biro Peradilan Agama No. 8/ 1/ 1935 tanggal 18 Februari 1958 mengenai kitab-kitab yang akan digunakan sebagai rujukan pembuatan putusan oleh Pengadilan Agama, juga menunjukkan bahwa upaya kodifikasi Hukum awal sudah dimulai, meskipun masih dalam bentuk yang sederhana dan masih mengacu pada kerangka berfikir ulama fikih.

Adapun pengakuan pemerintah terhadap hukum Islam sebagai hukum positif (ius constitum) nampaknya baru diberlakukan pertama kali sejak lahirnya UU No. 1 tahun 1974.

\footnotetext{
${ }^{20}$ Badan peradilan di Indonesia dibagi ke dalam empat lingkungan: 1) Peradilan Umum, 2) Peradilan Agama, 3) Peradilan Militer, dan 4) Peradilan Tata Usaha Negara. Lebih lanjut baca Pardoyo, Sekularisasi dalam Polemik, sekapur sirih Nurcholish Madjid Jakarta: Pustaka Utama Grafiti, 1993), hal. 173-242
} 
Meskipun masih bersifat umum, dalam pasal 2 ayat (1) UU tersebut dinyatakan, "perkawinan adalah sah, apabila dilakukan menurut hukum masing-masing agamanya dan kepercayaannya itu". Kemudian, pada pasal 63 ayat (1) ditegaskan bahwa "Pengadilan Agama seperti yang termaktub dalam pasal $10 \mathrm{UU}$ No. 14 tahun 1970 adalah dikhususkan bagi orang-orang yang beragama Islam.

Pada tahun-tahun berikutnya, terjadi kemajuan besar bagi hukum Islam dalam kerangka ius constitum dengan ditetapkannya UU No. 7 tahun 1989 tentang Peradilan Agama dan Inpres No. 1 tahun 1991 tentang Kompilasi Hukum Islam. Dengan kedua peraturan perundang-undangan tersebut, hukum Islam bukan saja diakui eksistensinya, akan tetapi secara definitif telah menjadi bagian dari hukum nasional dan pilar peradilan Negara, baik secara formil maupun materiil.

Lahirnya Kompilasi Hukum Islam (KHI) merupakan perkembangan terbaru dari upaya kodifikasi dan unifikasi hukum Islam di Indonesia. KHI tidak hanya mengkompilasi hukum-hukum yang sudah pernah digunakan sebelumnya dalam pembuatan keputusan Pengadilan Agama, melainkan juga mengkompilasi hukum-hukum baru dari berbagai mazhab hukum yang dirasa compatible dengan the living law, hukum dan tradisi yang hidup dimasyarakat. Keberadaannya juga semakin mempertegas eksistensi Pengadilan Agama di Indonesia sebagai salah satu dari 3 pilar yang disyaratkan harus ada dalam sebuah lembaga pengadilan, yaitu: 1) adanya badan peradilan, 2) fungsionalis (hakim, pengacara dan jaksa), dan 3) sumber rujukan hukum. ${ }^{21}$

Satu hal mendasar yang perlu dicermati dalam konteks ini adalah bahwa meskipun jika dilihat dari sudut eksistensinya hukum Islam sudah sedemikian diperhitungkan dalam tata hukum nasional, namun sekali lagi ruang lingkup serta otoritasnya sebagai hukum positif masih berada dipersimpangan jalan. Hal

${ }^{21}$ Imam Mawardi, "Rationale., hal. 100 
ini tentunya tidak sebanding dengan kapabilitas hukum Islam itu sesungguhnya dalam menawarkan alternatif keadilan bagi para pencarinya.

Keberadaan tata hukum Indonesia yang menganut aliran positivisme yuridis, ${ }^{22}$ nampaknya bisa dijadikan salah satu alasan mengapa terjadi kesenjangan antara posisi dan ruang lingkup hukum Islam dalam tata hukum nasional (das sein) dengan kemampuan dan ruang lingkup sesungguhnya dari hukum Islam itu sendiri (das sollen).

Berdasarkan karakter aliran positivisme yuridis, maka yang dapat diterima sebagai hukum yang sebenarnya hanya yang telah ditentukan secara positif oleh negara, tidak terkecuali hukum Islam. Lebih jauh, Mahfud MD menyatakan dalam disertasinya bahwa karakter suatu produk hukum senantiasa dipengaruhi atau ditentukan oleh konfigurasi politik di mana hukum itu lahir dan berkembang. Artinya, konfigurasi politik tertentu dari suatu kelompok dominan akan selalu melahirkan karakter produk hukum tertentu pula sesuai dengan visi dan misi politiknya. ${ }^{23}$

\section{Penutup}

Berdasarkan uraian di atas, nampak jelas bahwa hukum Islam telah mengalami proses dialektika yang panjang dan kompleks sehingga kemudian dapat menemukan bentuknya seperti sekarang. Tarik ulur yang terjadi antara hukum adat, kebijakan pemerintah kolonial dan hukum Islam itu sendiri, nampaknya telah memberi warna khas terhadap wajah hukum Islam di Indonesia.

Sangat tidak beralasan jika para peneliti menyimpulkan bahwa format hukum Islam di Indonesia bukanlah cerminan dari wajah

${ }^{22}$ Positivisme yuridis didasari oleh aliran hukum humanisme dengan tokohnya antara lain Jean Bodin yang mencetuskan ide-ide tentang kedaulatan raja. Tokoh positivisme yuridis itu sendiri adalah Rudolf von Jehring (1818-1892) yang menganut paham bahwa hanya apa yang ditetapkan sebagai kenyataanlah yang dapat diterima sebagai kebenaran. Lihat Theo Huijbers, Filsajat Hukum Islam dalam Lintasan Sejarab (Jogjakarta: Kanisius, 1982), hal. 122130

${ }^{23}$ Moh. Mahfud MD, Politik Hukum di Indonesia (Jakarta: LP3ES, 1998), hal. 13 
hukum Islam yang sebenarnya. Atau, mengidentikkan keislaman di Indonesia dengan keisalaman di Timur Tengah (Arab) nampaknya juga upaya yang terlalu terburu-buru. Dan dalam pengembangan kajian keisalman, hal tersebut nampaknya kontraproduktif mengingat para ulama di kepualauan nusantara telah melakukan sebuah ijtihad nan brilliant sehingga mampu menampilkan wajah Islam yang benar-benar șălibun li kulli zamānin wa makānin. Meskipun hal ini berimplikasi pada munculnya wajah keislaman yang khas Indonesia dan sedikit berbeda dengan daerah dimana ajaran Islam itu dilahirkan.

Pada perkembangan yang paling mutakhir, konfigurasi politik dan dinamika masyarakat Indonesia yang kian kompleks telah mengantarkan hukum Islam pada suatu perubahan besar. Model penyampaian hukum Islam ala fikih klasik telah berkembang menjadi peraturan perundang-undangan yang menjelma dalam bentuk Kompilasi Hukum Islam. Dan beberapa materi hukum yang terdapat dalam Kompilasi tersebut juga telah menunjukkan bahwa perubahan sosial di masyarakat juga ikut menentukan kemana aturan hukum itu akan dirumuskan. 


\section{DAFTAR PUSTAKA}

Azizy, Qodri. Hukum Nasional: Eklektisisme Hukum Islam dengan Hukum Umum. Jakarta: Teraju, 2004.

Azra, Azyumardi. Jaringan Ulama Timur Tengah dan Kepulauan Nusantara Abad XVII dan XVIII. Jakarta: Kencana, 2004.

Coulson, N.J. Konflik dalam Jurisprudensi Islam, alihbahasa Fuad Zein. Yogyakarta: Navila, 2001.

Gunawan BS, Ahmad dan Mu'amar Ramadhan. Menggagas Hukum Progresif Indonesia. Yogyakarta: Pustaka Pelajar, 2006.

Hasaballāh, Afi. Ușūl at-Tasyrī' al-Islāmī. Mesir: Dār al-Ma’ārif, t.t.

Hazairin. Tujub Serangkai tentang Hukum. Jakarta: Tintamas, 1974.

Huijbers, Theo. Filsafat Hukum Islam dalam Lintasan Sejarah. Yogyakarta: Kanisius, 1982.

Khallāf, Abdul Wahāb. Ilmu Ușul Fiqh. Kuwait: Dār al-Ilm, 1978.

Lukito, Ratno, Tradisi Hukum Indonesia, Jogjakarta: Teras, 2008.

Mahfudz, Sahal. Nuansa Figh Sosial. Yogyakarta: LKiS, 2003.

Mahfud M.D., Moh. Politik Hukum di Indonesia. Jakarta: LP3ES, 1998. 
Wahid, Marzuki dan Rumadi. Fikih Mazhab Negara. Yogyakarta: LKiS, 2001.

Ali, Muhammad Daud. "Hukum Islam; Peradilan Agama dan Masalahnya", dalam Eddi Rudiana Arief et.al. (Peny.). Hukum Islam di Indonesia. Bandung: Rosdakarya, 1991. Pardoyo. Sekularisasi dalam Polemik. Jakarta: Pustaka Utama Grafiti, 1993.

Ichtijanto, S.A., S.H. Hukum Islam dan Hukum Nasional. Jakarta: Ind-Hill-Co, 1990.

Raharjo, Satjipto. Ilmu Hukum. Bandung: Citra Aditya Bakti, 1996.

Sembodo, Cipto. "Reintroduksi Hukum Islam dalam Wacana Kebangsaan," as- Supena, Ilyas dan M. Fauzi. Dekonstruksi dan Rekonstruksi Hukum Islam. Yogyakarta: Gama Media, 2002.

Sunny, Ismail. "Kedudukan Hukum Islam dalam Sistem Ketatanegaraan Indonesia", dalam Munawir Sadzali dan Juhaya S. Praja, Hukum Islam di Indonesia. Bandung: Remaja Rosdakarya, t.t.

Teba, Sudirman (Ed.). Perkembangan Mutakbir Hukum Islam di Asia Tenggara. Bandung: Mizan, 1993.

Thalib, Sajuti. Receptio a Contrario: Hubungan Hukum Adat dengan Hukum Islam. Jakarta: Bina Aksara, 1985. 
Agus Sunaryo 